\title{
MAUZOLEUM PRZEKSZTALCONE W ELITARNY CMENTARZ? O POCZĄTKACH NEKROPOLI W BODZI
}

\author{
A MAUSOLEUM TURNED INTO AN ELITE CEMETERY? \\ THE ORIGIN OF THE BODZIA NECROPOLIS
}

\begin{abstract}
The elite cemetery in Bodzia (from the late 10th to the early 11th centuries) hosts the deceased of foreign and local origin who had a strong sense of ideological and ethno-cultural bonds. According to the results of the author's latest research, a large tomb D162 played a pivotal role in the cemetery. It was originally built as a grave - a mausoleum with an entrance from the east. Over time, more graves with enclosures were added to the existing tomb on the eastern side, imitating architecture of a primary grave. The successive burials in which remains of foreigners were identified represented the structural first degree elements of the cemetery. In line with the results of isotopic labelling, the group of people buried in this row is associated with newcomers from the Baltic (Scandinavian) zone.

In search of the sources of the idea and, further on, the model of the cemetery, attention was directed at the symbols and the structural elements of royal courts and rural aristocratic mansions, especially rectangular plots of land with enclosures as known from Denmark.
\end{abstract}

Keywords: funerary patterns, medieval elites, primary graves, Danish feudal estates, Jelling monumental complex

\section{WPROWADZENIE}

Cmentarzysko w Bodzi k. Włocławka, choć zostało opublikowane kilka lat temu (por. Buko red. 2015; 2016; por. też Buko i in. 2014), nadal generuje wiele pytań i tym samym pozostaje w grupie odkryć archeologicznych o znaczeniu szczególnym. Przypomnijmy, że pochowano tam niewielką, elitarną grupę ludzi miejscowych i przybyłych z zewnątrz, związanych ze środowiskami kultur słowiańskiej, nomadzkiej i skandynawskiej. Rzędy cmentarza wyznaczone są liniami grodzeń, w których obrębie zachowały się elementy konstrukcji w typie grobów komorowych, ale również komór z aneksami, charakterystycznych dla środowiska noma-

\footnotetext{
* Instytut Archeologii i Etnologii Polskiej Akademii Nauk, al. Solidarności 105, 00-140 Warszawa.
} 


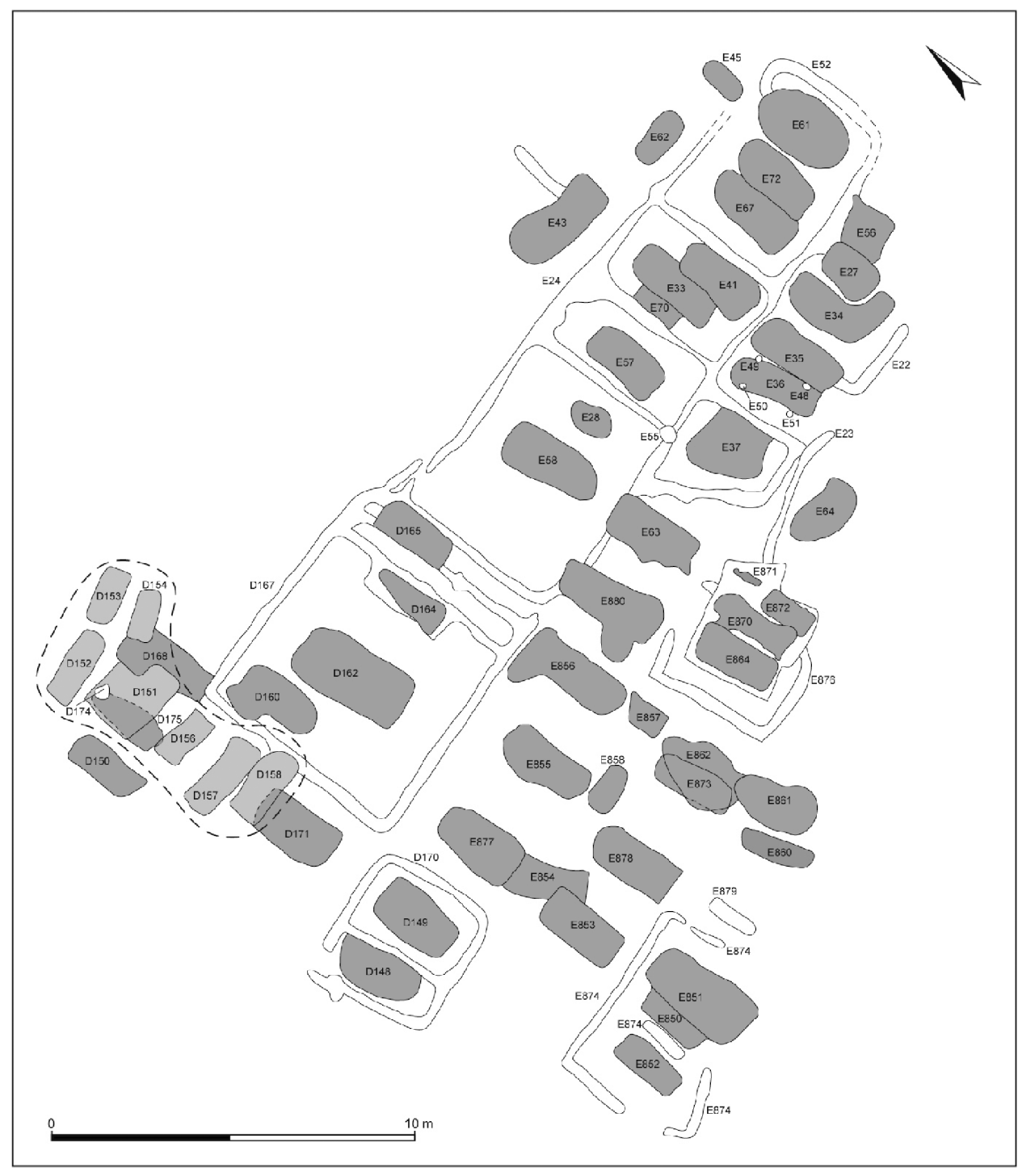

$-A \quad \square-B$

Ryc. 1. Układ przestrzenny cmentarzyska w Bodzi (wg I. Sobkowiak-Tabaka)

dów (Chazarów). Odmienna od dominującej w tym czasie w Polsce i Europie pozostaje tam reguła północnej orientacji zmarłych oraz bogactwo ich wyposażenia. Czas funkcjonowania cmentarza wyznacza schyłek X i pierwsze dekady XI wieku. Jako całość nie znajduje on analogii w skali europejskiej. 
Cmentarz usytuowano w miejscu przylegającym do szlaku środkowej Wisły, który łączył we wczesnym średniowieczu szeroko rozumianą strefę Morza Bałtyckiego z terenami południowo-wschodniej Europy i dalej - z cywilizacją bizantyjską (por. Bogucki 2016a). Stąd nie przypadkiem na wschód od interesującego nas terytorium - w kraju Prusów, jeszcze przed powstaniem państwa polskiego zaistniało „duńskie” Truso (por. Jagodziński 2010).

W przetrwałej do naszych czasów topografii nekropoli widoczne są cztery wyraziste rzędy, w obrębie których zidentyfikowano przeważającą większość pochówków zorientowanych, poza paroma wyjątkami, na linii N-S. Osią organizującą są groby i towarzyszące im grodzenia rzędu I, licząc od strony północnej. Tutaj zidentyfikowano aż 13 komór grobowych; kolejnych 6 (poza obrębem grodzeń) zaliczonych do tej samej fazy znajduje się po stronach zachodniej i północnej rzędu (ryc. 1).

W rzędach II-IV pochówki występują zarówno w obrębie grodzeń, jak i poza nimi. Zróżnicowane są tutaj ich formy oraz odnotować należy brak dokładnej osi symetrii. Liczne są natomiast komory grobowe $\mathrm{z}$ aneksami. W III rzędzie cmentarza przeważają groby bez grodzeń, a wokół kwatery związanej z młodym wojownikiem (E864/I) grodzenia przyjmują niespotykane wcześniej kształty.

Rudymentarne znaczenie ma IV (południowy) rząd cmentarza. Udokumentowano tu tylko trzy pochówki, zdeponowane w obrębie grodzenia o niejasnej do końca formie oraz dwa groby bez grodzeń. Na tym etapie zaprzestano dalszego grzebania zmarłych.

Cmentarz jako całość tworzy czytelny i oryginalnie zaprojektowany wzorzec przestrzenny (cztery równoległe osie nekropoli) i strukturalny (duże komory grobowe i wokół nich grodzenia), choć każdemu rzędowi przypisać można inne cechy go wyróżniające. Różnicują je wielkości i forma grodzeń i komór grobowych oraz obecność pochówków bez grodzeń; te ostatnie występują zarówno na głównych osiach nekropoli, jak i poza ich obrębem. Odkrycia archeologiczne ukazują nekropolę dynamicznie zmieniającą się w czasie, zarazem pełną innowacji.

Uwagę przyciągają grodzenia zachowane wokół większości grobów. Ich materialnym świadectwem są ich negatywy zachowane na poziomie spągu. Formy i wymiary tych ostatnich są różne: od prostokątnych, poprzez trójkątne w przekroju, po zagłębione meniskowato w ziemię. Obserwacje te nasuwają wiele możliwości interpretacyjnych: od zwykłych rowów, poprzez proste płoty, grodzenia typu palisadowego, a może nawet tzw. domy zmarłych. Ale odtworzenie pierwotnej formy tych konstrukcji jest trudne, zważywszy na to, że na zachowanym (najniższym) poziomie cmentarza odsłonięto zachowane niekiedy śladowo tylko ich przydenne, negatywowe części. Co więcej, na niektórych odcinkach negatywów jest w ogóle brak.

Rozmaitość szczegółów konstrukcyjnych grobów i grodzeń wskazuje, że ich elementy konstrukcyjne podlegały w miarę upływu czasu określonym modyfikacjom. Natomiast trwała okazała się koncepcja podziału cmentarza na rzędy i okazałe wielkością komory grobowe. W mniejszym stopniu przestrzegano norm 


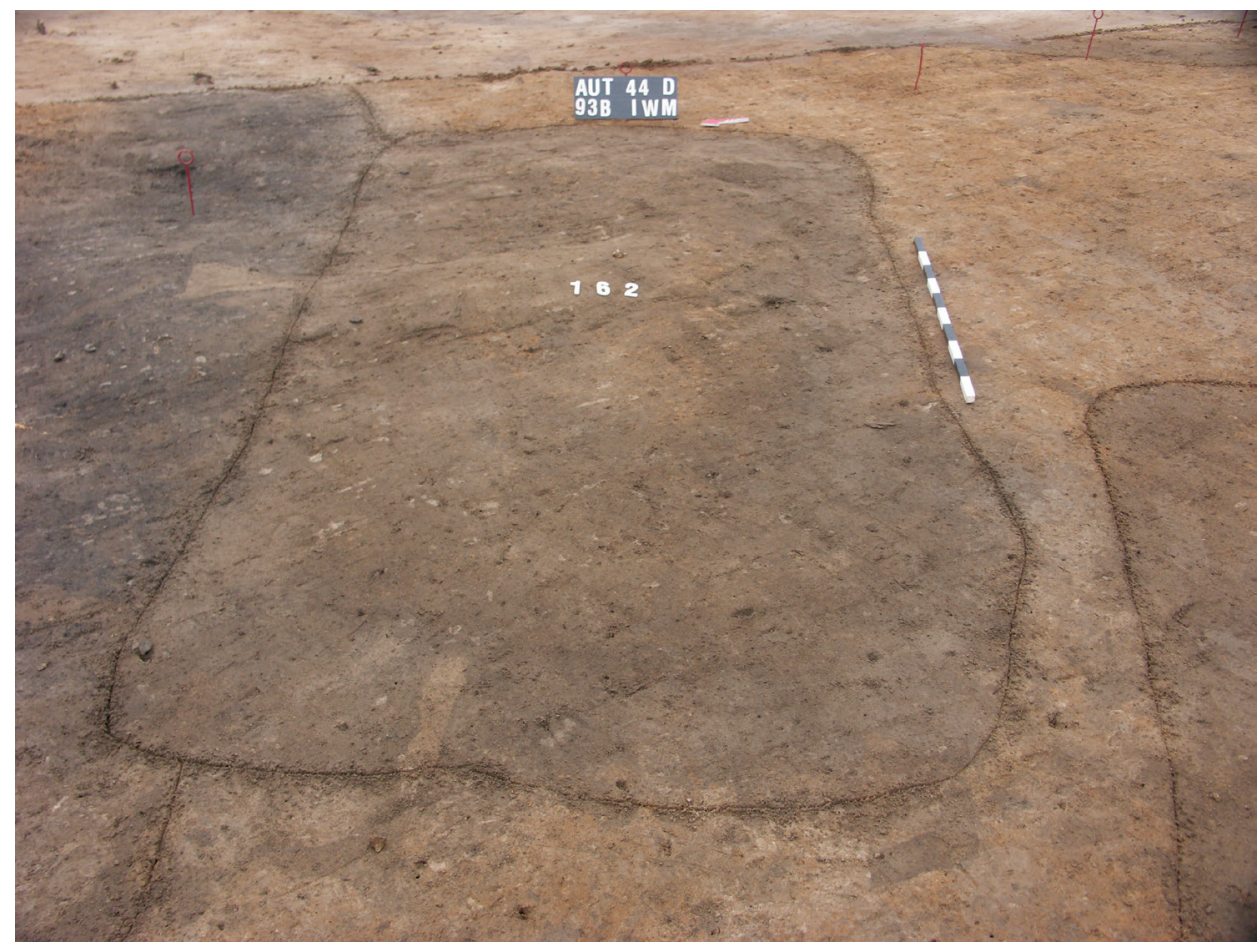

Ryc. 2. Komora grobowa D162: widok od strony północnej na poziomie eksploracji. Po lewej stronie pradziejowy obiekt kultury łużyckiej (D163), na prawo - krawędź wkopu grobowego D160 (fot. S. Gronek)

dotyczących kształtu grodzeń oraz wymogu składania w ich obrębie wszystkich zmarłych. Wydaje się, że w miarę upływu czasu (rzędy II-IV) grodzenia, w tym ich formy i wielkości, wyraźnie traciły na znaczeniu. Powstaje pytanie: który grób wyznacza początek (fazę inicjalną) cmentarza, tym samym, który uznać można za prymarny? Na tym tle uwagę zwraca oznaczony numerem D162, usytuowany po stronie zachodniej I rzędu cmentarza.

\section{GRÓB D162: KOMORA GROBOWA, POCHÓWEK I JEGO WYPOSAŻENIE}

Jest to najbardziej reprezentatywny, pod względem wielkości komory grobowej i grodzenia, pochówek w obrębie cmentarza (por. ryc. 1). Zmarły złożony został w największej spośród wyróżnionych w obrębie cmentarza komorze grobowej, usytuowanej centralnie wewnątrz największego, prostokątnego grodzenia.

Komora grobowa (największa w obrębie cmentarza) ma tu kształt prostokątny, z lekko zaokrąglonymi narożnikami (ryc. 2). Jej długość wynosi 339 cm, przy 


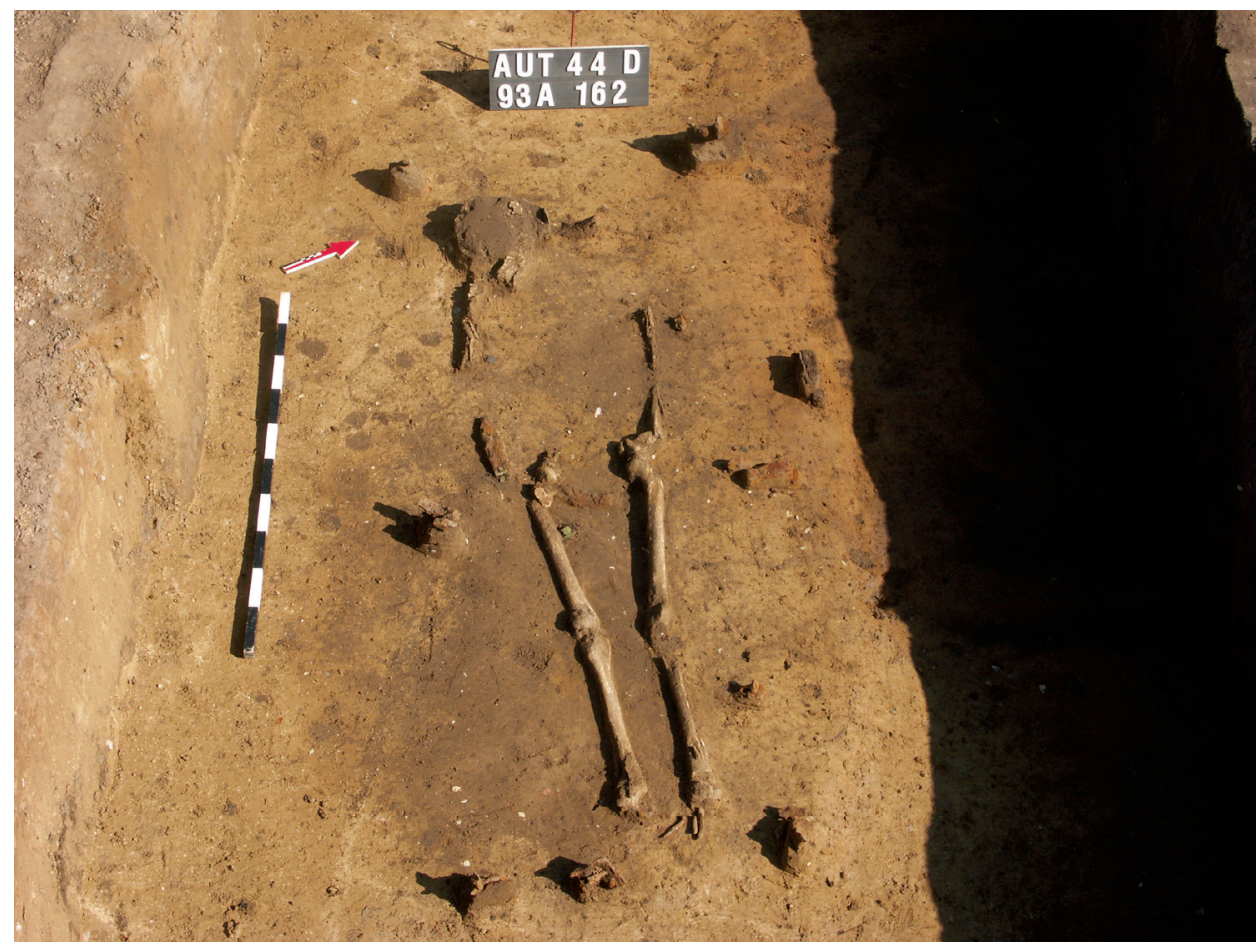

Ryc. 3. Zmarły D162 w obrębie obszernej wyeksplorowanej komory grobowej. Wokół szkieletu widoczne metalowe okucia skrzyni trumiennej (fot. S. Gronek)

szerokości 162 i głębokości 55 cm. Wykluczyć nie można (por. niżej), że pierwotnie jej ściany obudowane były drewnem. Wypełnisko jamy grobowej stanowiła brunatna próchnica, z niewielką domieszką gliny (Sobkowiak-Tabaka 2016, s. 70).

Wewnątrz komory zidentyfikowano elementy trumny w postaci 10 żelaznych okuć trumiennych (ryc. 3). Na dwóch zachowały się resztki zmineralizowanego (?) drewna sosnowego (Pinus sylvestris L.) oraz węgle drzewne pochodzące $\mathrm{z}$ dębu (Quercus sp.). Dobrze zachowało się pięć okuć trumiennych, podczas gdy pozostałe pięć stanowią ich fragmenty. Wszystkie taśmy okuć są do siebie podobne. Ich układ przestrzenny i widoczny w podłożu ślad po trumnie wskazują, że skrzynia trumienna była prostokątna o długości około $2 \mathrm{~m}$ i szerokości około $65 \mathrm{~cm}$, z dwuspadowym wiekiem (ryc. 4). Odnotowano jej podobieństwo do skrzyni trumiennej z grobu D164 - kobiety o obcym, skandynawskim (?) rodowodzie, pochowanej ,w przedsionku” grobowca; jest to jedyny stwierdzony w przypadku Bodzi przypadek powtarzalności formy trumny (por. Sawicki 2016, s. 395).

Odkryty w grobie D162 szkielet należy do mężczyzny (?) w wieku maturus (35-45 lat) ułożonego na linii N-S w pozycji na wznak, z głową skierowaną w kie- 


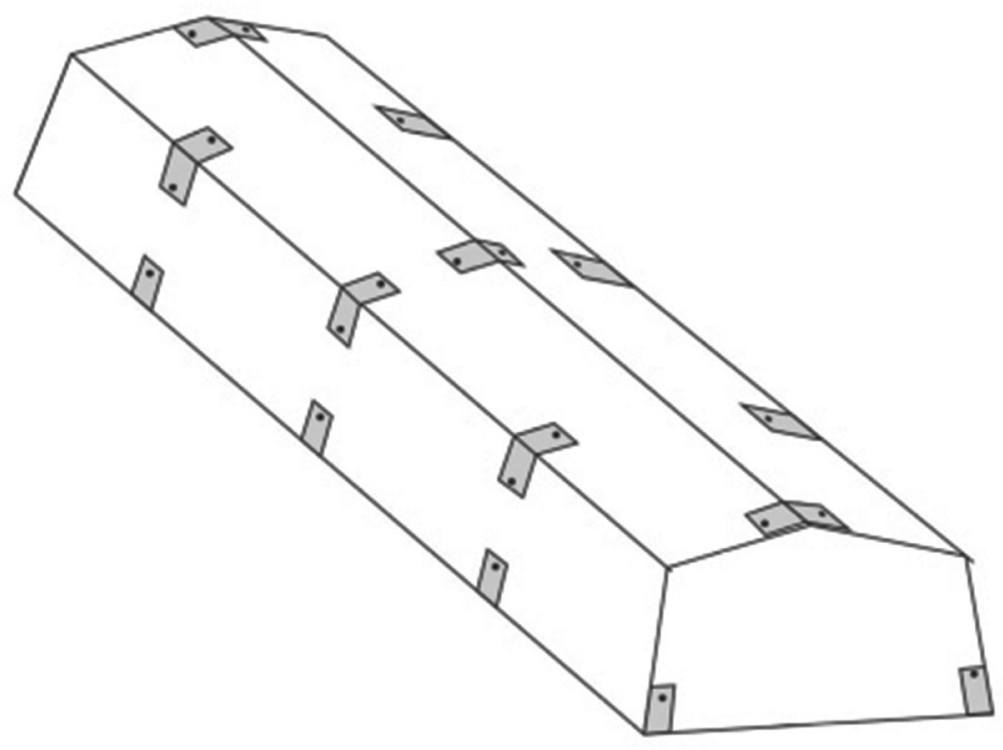

Ryc. 4. Trumna z grobu D162: próba rekonstrukcji (wg T. Sawickiego)

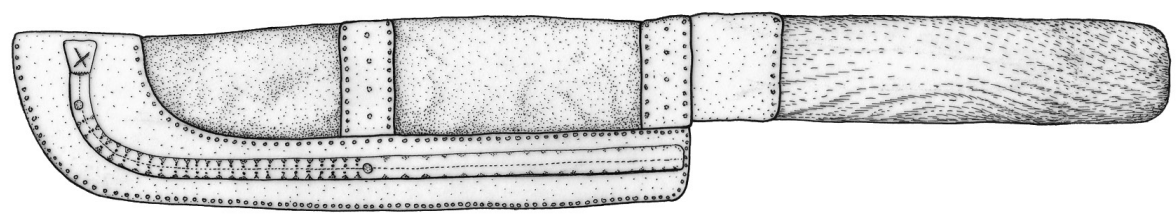

Ryc. 5. Ozdobna pochewka noża znaleziona przy szkielecie D162: próba rekonstrukcji (wg A.B. Kowalskiej)

runku północnym. Kończyny górne i dolne wyprostowane były wzdłuż ciała, przy czym kości zmarłego są słabo zachowane (por. ryc. 3). Nie stwierdzono na nich zmian patologicznych.

Przy szkielecie znaleziono wyposażenie. Składają się na nie ozdoby i części stroju, narzędzia, monety oraz fragment naczynia drewnianego (?). Do pierwszej grupy zaliczyć należy fragment zmineralizowanej tkaniny lnianej o wymiarach około $8 \times 2 \mathrm{~cm}$, zachowany przy skórzanej pochewce żelaznego nożyka, fragment blaszki brązowej (prawdopodobnie okucie końca pasa). Uwagę zwraca nóż w skórzanej pochewce z brązowymi okuciami powyżej prawego biodra. Na pochewce zachowane są pozostałości trójkątnej w przekroju brązowej, zdobionej listwy. Jej funkcja 
mogła być zarówno ozdobna, jak i konstrukcyjna (ryc. 5). Anna Kowalska odnotowuje, że przekrój listwy na pochewce z Bodzi oraz jej charakterystyczne zakończenie nawiązują do odkryć znanych z kilku cmentarzysk w różnych częściach Polski. Tego typu zdobienia sugerują produkcję tych przedmiotów w kręgu skandynawskim lub pod silnym wpływem sztuki normańskiej. Autorka ta sugeruje zarazem, że południowa Rosja lub Bizancjum- mogą być obszarami, skąd wywodzić się może ta tradycja. Zwraca też uwagę na umieszczony na płaskiej części listwy pochewki z Bodzi znak „X”, który skłonna jest interpretować jako znak krzyża św. Andrzeja (Kowalska 2016, s. 264).

Z grobu D162 pochodzą dwie monety. Jedna z nich umieszczona została przy głowie $\mathrm{z}$ prawej strony, podczas gdy drugą udokumentowano po prawej stronie klatki piersiowej. Są to denar krzyżowy typu I (2. połowa X w.), wybity w Saksonii oraz denar Bolesława II (emisja 972-999), wybity w Czechach około 985-995 (Suchodolski 2016, s. 285, 293). W warstwach wypełniska komory grobowej wystąpiło też 168 fragmentów ceramiki z różnych okresów chronologicznych, zalegającej tu na złożu wtórnym, tym samym należących do innych kontekstów stratygraficznych (por. Sobkowiak-Tabaka 2016, aneks 2.3). Intencjonalny charakter ma natomiast spiralne skupisko węgli drzewnych pochodzących z dębu, udokumentowane w południowo-zachodnim narożniku jamy grobowej. Na ich zakładzinową (?) funkcję zwrócił uwagę M. Kara (2016a, s. 357).

W świetle wyników analizy materiału numizmatycznego grób D162 zaliczyć należy do najstarszych w obrębie cmentarza i datować go na okres około $985 \mathrm{r}$. (por. Suchodolski 2106, s. 295). Ustaleniom tym nie przeczą zarówno dane archeologiczne (por. Buko, Kara 2016, s. 449, 451), jak i radiowęglowe (por. Goslar 2016; Krąpiec 2016). Tym samym można przyjąć z dużym stopniem prawdopodobieństwa, że zmarłego pochowano jeszcze przed schyłkiem $\mathrm{X}$ wieku.

\section{OTOCZENIE GROBU: NEGATYWY PROSTOKĄTNEGO GRODZENIA}

Elementem organizującym I rząd, a zarazem osie cmentarza tworzą grodzenia, których negatywy odsłonięto na poziomie gliniastego calca (por. ryc. 1). Poszczególne komory grobowe rozgraniczały wąskie rowy o szerokości około 0,2-0,3 m i zachowanej głębokości średnio około 0,2 m, wypełnione jednorodną próchnicą. Spąg tych rowów określany jest jako spiczasty lub zaokrąglony (por. Kara 2016a, s. 337). Najbardziej regularny jest rów o głębokości około 0,3 m i szerokości 0,25-0,30 m (obiekt D167), zatem zidentyfikowany wokół grobu D162. Ma on regularną czworokątną formę oraz brunatne, próchniczne wypełnisko (ryc. 6).

Inne grodzenia tego samego rzędu, choć mają różne wielkości, są symetryczne względem siebie, a punktem odniesienia symetrii jest ich południowa krawędź. Jest to jednocześnie oś podstawowego podziału przestrzeni cmentarza na część północną - z prostokątnymi grodzeniami wokół grobów, uporządkowaną geometrycznie, 


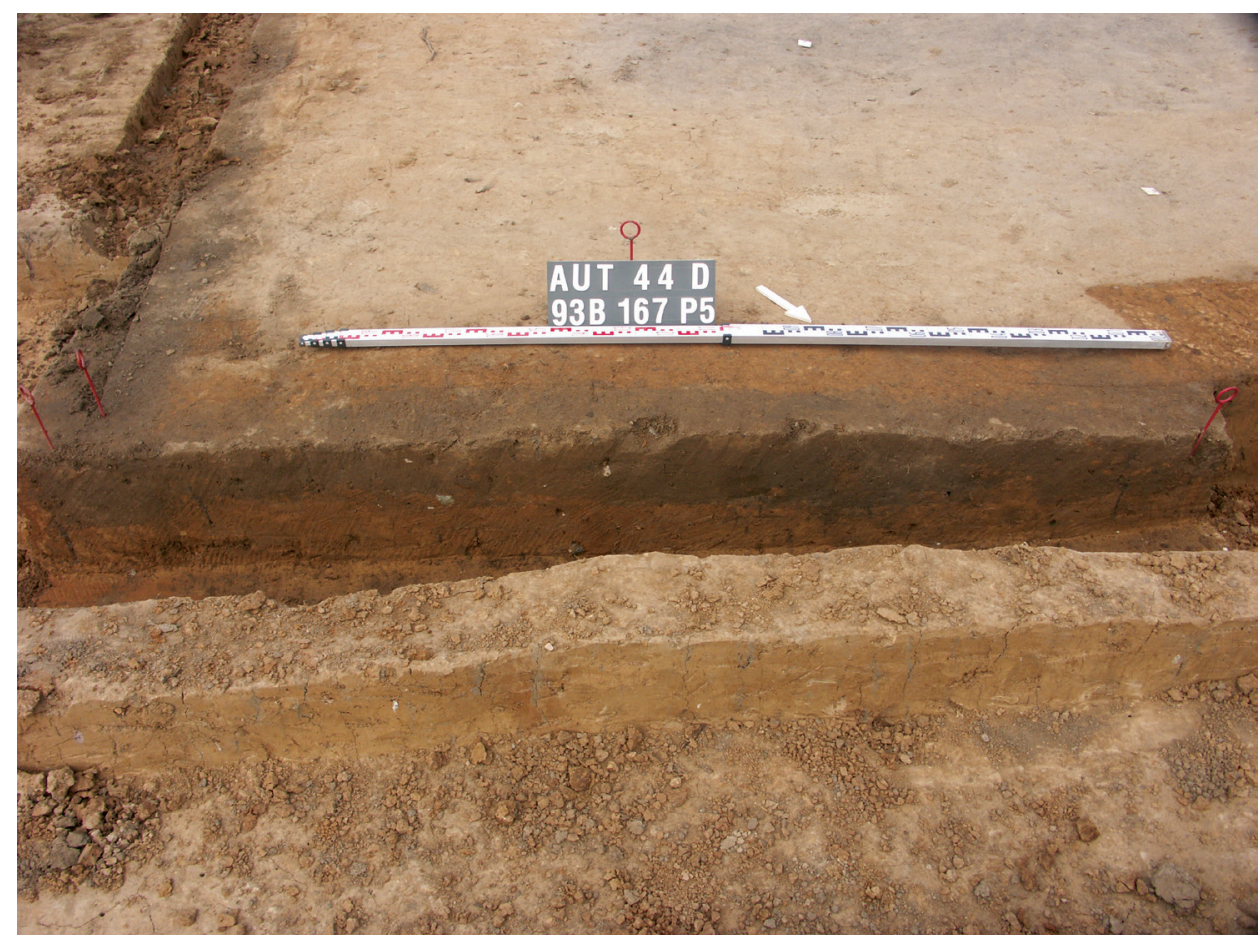

Ryc. 6. Prostokątny negatyw grodzenia kwatery D162 (część wschodnia) w trakcie eksploracji: przekrój wypełniska (fot. S. Gronek)

oraz część południową - w której występują zarówno pochówki z grodzeniami, jak i bez nich (ryc. 7). Obserwujemy też sukcesywne zmniejszanie się rozmiarów grodzeń rzędu I w kierunku wschodnim. Następuje przy tym coraz bardziej szczelne wypełnianie ich przestrzeni wewnętrznej pochówkami. Liczba zmarłych deponowanych w obrębie jednego grodzenia- nie przekracza jednak w rzędzie I trzech osobników.

Prostokątne grodzenie o wymiarach $748 \times 640 \mathrm{~cm}$ i głębokości 0,32 m zidentyfikowane wokół grobu D162 jest dobrze czytelne (ryc. 8). Jego ściany: północna, południowa i zachodnia są względem siebie symetryczne i mają regularny przebieg. Jedynie negatyw zachodni jest lokalnie uszkodzony przez jamy późniejszych komór grobowych. Ponieważ obserwacja ta dotyczy spągu cmentarza, nie można wykluczyć, że na pierwotnej powierzchni terenu groby sąsiednie nie tyle uszkadzały, ile przylegały do grodzenia. Jeżeli tak było, to relacje stratygraficzne oglądane na poziomie spągu wynikać mogą z braku precyzji kopania (w pionie) komory grobowej. Pomimo iż część pochówków zlokalizowanych po stronie zewnętrznej i należących do młodszej fazy cmentarza (2. połowa XI w.) znajduje się W bezpośrednim sąsiedztwie grobu D162, to żaden z nich nie wkracza głębiej 


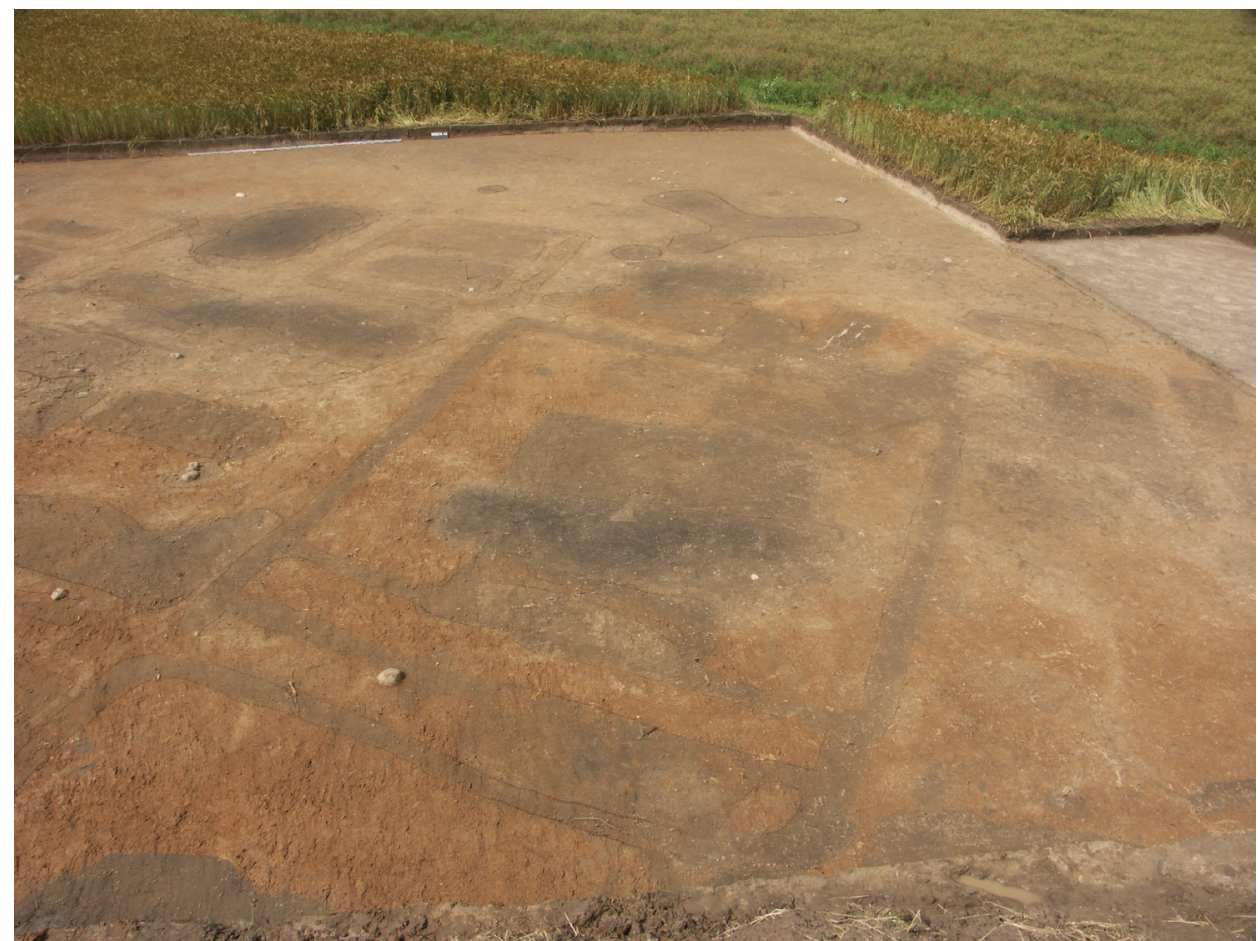

Ryc. 7. Negatyw grodzenia D167, obiekty i komory grobowe. Widok z góry od strony północno-wschodniej (fot. S. Gronek)

aniżeli do negatywowych wkopów grodzenia D167, które niewątpliwie są szersze aniżeli posadowione weń słupy palisady. Oznaczać to może, że elementy zewnętrzne tego grodzenia były wówczas nadal w jakiś sposób widoczne na powierzchni i trwała pamięć o osobie/osobach pochowanych w jego obrębie.

Negatywy północny i południowy grodzenia są w przekroju prostokątne i podobnie ukształtowane, a ich wypełnisko stanowi brunatna ziemia próchniczna (Kara 2016a, s. 337). Nadal dobrze zaznaczone są ich krawędzie i delikatne ich wybrzuszenia. Odnotujmy też ich lekko zaokrąglone krawędzie w miejscach styku negatywów (por. ryc. 8).

Inaczej względem dotąd opisywanych prezentuje się zamknięcie grobu D162 po stronie wschodniej. Mamy tu co najmniej dwie linie równoległych negatywów. Negatyw wewnętrzny jest w części centralnej uszkodzony przez wkop grobu D164. Podobnie jak w opisywanych wcześniej przypadkach, ma on krawędzie lekko faliste, a dotyczy to zarówno strony zewnętrznej, jak i wewnętrznej. Widoczna w środkowej części prostokątna wnęka sugerować może obecność w tym miejscu pierwotnego wejścia na teren grodzenia. 


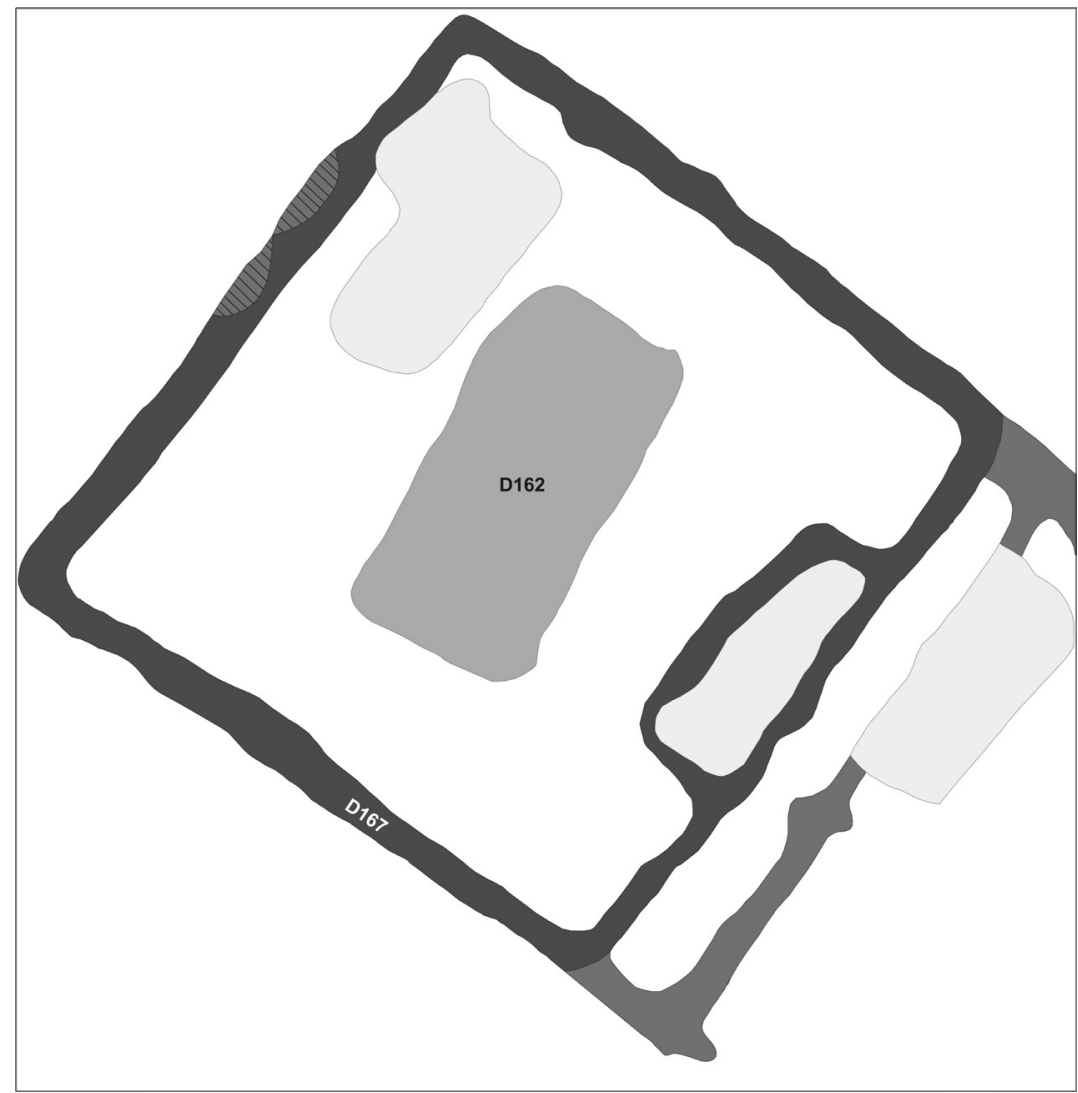

Ryc. 8. Negatyw grodzenia D167 zidentyfikowany wokół grobu D162. Uwagę zwracają lekko pofalowane krawędzie grodzenia (świadectwa obecności w rowkach słupów palisady?). Kolorem jaśniejszym (po prawej stronie) oznaczono część grodzenia D167 przyporządkowaną do II fazy użytkowania grobowca (na podstawie dokumentacji stanowiska przechowywanej w PMA, opracowała komputerowo K. Skrzyńska)

Równolegle względem opisywanego, po jego prawej stronie, w odległości około $50 \mathrm{~cm}$ w kierunku wschodnim, widoczny jest kolejny negatyw, uszkodzony wkopem grobu D165, który ma podobną szerokość. Jego krawędzie są również lekko faliste, przy czym po stronie południowej, tuż obok wkopu grobowego D165, widoczny jest owalny negatyw po palu (?), o średnicy niemal $50 \mathrm{~cm}$. Po stronach południowej i północnej opisywany negatyw grodzenia ma bezpośredni styk z pozostałymi, przy czym po stronie południowo-wschodniej kończy się charakterystycznym występem (por. ryc. 1, 8). 
Trzy pochowki (D160, D164, D165) zidentyfikowane wewnątrz grodzenia D167 zostały weń wbudowane wtórnie. Wynika to zarówno z obserwacji ich pozycji stratygraficznej (naruszają częściowo strukturę grodzenia D167), jak i peryferyjnej, w stosunku do grobu centralnego (D162), lokalizacji. Pierwszy z nich (D160), z niszą po stronie zachodniej, zawierający szczątki mężczyzny najpewniej obcego (skandynawskiego?) pochodzenia w wieku adultus (por. Price, Frei 2016, s. 433), znajduje się tuż przy ścianie zachodniej grodzenia. Z kolei pochówek kobiecy (D164) w wieku adultus/maturus (30-40 lat) wbudowano w część przedsionka (?) po stronie wschodniej (por. ryc. 1). Grób nie narusza pierwotnej konstrukcji grodzenia, co świadczy, że w momencie składania zwłok zmarłej w drewnianej trumnie- respektowano dotychczasowy układ przestrzenny. Tego samego nie da się powiedzieć o grobie mężczyzny D165. W przeciwieństwie do omawianych dotąd, niszczy on po stronie wschodniej część konstrukcji grodzeniowych. Oznaczać to może, że w momencie gdy składano zwłoki zmarłego, tradycja kwater nie była już przestrzegana, a zewnętrzne ich elementy konstrukcyjne zostały usunięte.

\section{MONUMENTALNY GROBOWIEC NA KULMINACJI?}

Osobliwości grobowca D162 podkreślają zarówno jego cechy konstrukcyjne, jak i wyjątkowe miejsce $\mathrm{w}$ przestrzeni cmentarza. Zastanawia nietypowe, wielokrotne zamknięcie grodzenia po stronie wschodniej, czyli tam, gdzie przylega doń pochówek E58 (wojownik z langsaksem). Jeżeli grób D162 wyznaczał jedynie początek I rzędu cmentarza, to taki sposób zamknięcia kwatery w tym miejscu byłby konstrukcyjnie niezrozumiały.

Inaczej przedstawiają się możliwości interpretacji charakteru grodzenia przy założeniu, że pierwotnie w tym miejscu usytuowane było wejście na teren kwatery grobu D162. Jeżeli tak, to dwudzielne zamknięcie kwatery po stronie wschodniej wskazywałoby, że znajdował się tu pierwotnie rodzaj przedsionka (?), w który sukcesywnie wbudowano słup-drewnianą stellę (?), której negatyw widoczny jest w obrysie grodzenia (por. ryc. 8). Jeżeli tutaj było wejście, to przyjąć należałoby, że pierwotnym zamiarem było zbudowanie na kulminacji morenowego wyniesienia pojedynczego, monumentalnego grobowca.

Grobowiec D162 nie był w fazie najstarszej jedynym elementem krajobrazowym tego miejsca. U podnóża kulminacji, po jej stronie wschodniej, występuje bowiem zagadkowa struktura owalna, oznaczona numerem E52. Została ona uszkodzona przez komorę grobową E61, zatem jest od niej stratygraficznie starsza (por. ryc. 1). M. Kara (2016a, s. 339) sugeruje jej związek z rytuałami składania zmarłych do grobu w okresie, gdy przestrzeń ta nie była jeszcze zajęta przez pochówki cmentarza. Możliwe jest też zaproponowanie hipotezy alternatywnej. Jeżeli 


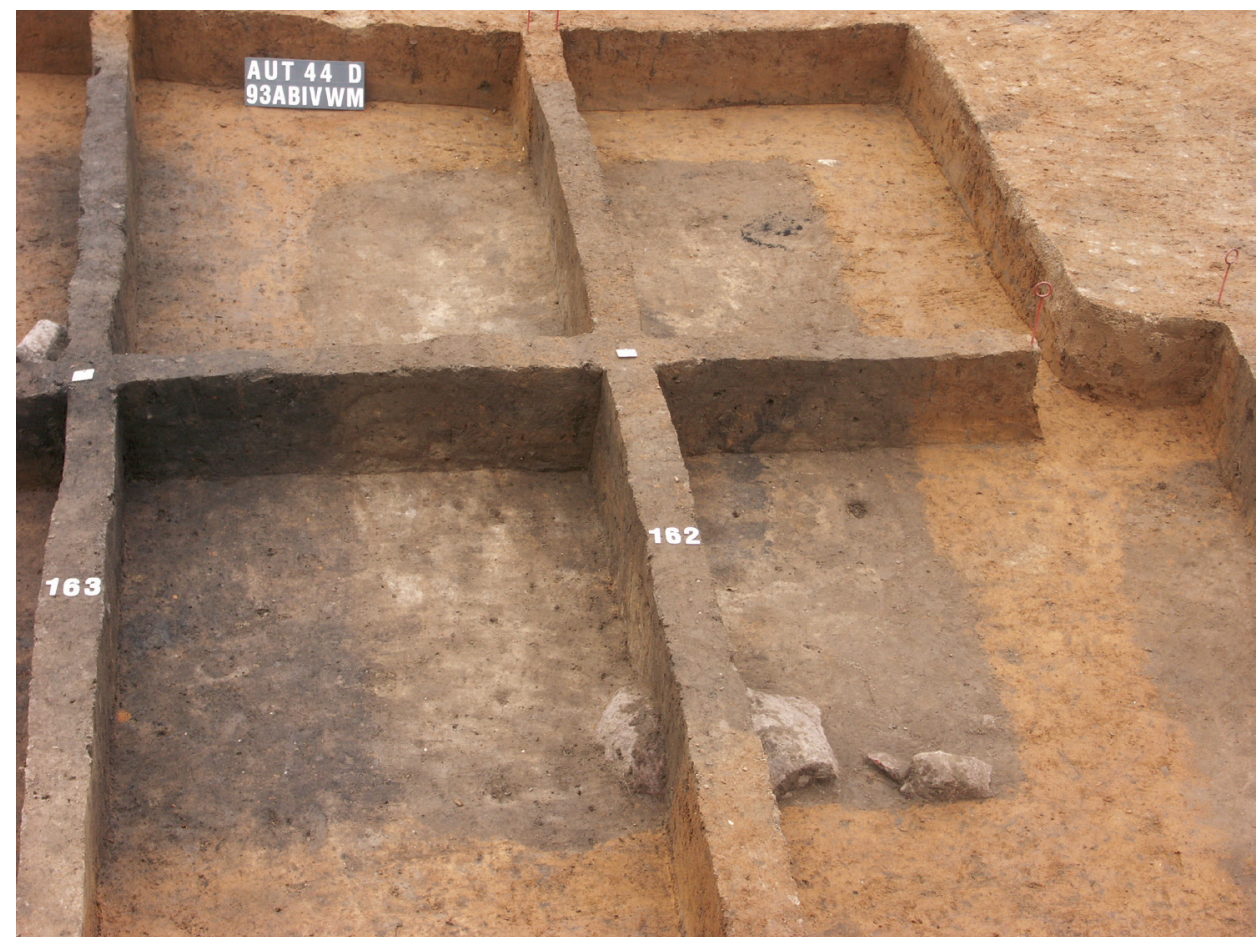

Ryc. 9. Komora grobu D162 od strony północnej. Na pierwszym planie głaz kamienny zalegający w wypełnisku, powyżej spągu jamy grobowej (fot. S. Gronek)

okazały grobowiec-mauzoleum (?) był w fazie inicjalnej głównym elementem krajobrazowym, to struktura u podnóża wzgórza mogła być strażnicą (?) tego miejsca pamięci. W momencie przekształcenia stoku wzgórza w rząd elitarnego cmentarza, funkcja ta straciła rację bytu, tym samym obiekt E52 został zlikwidowany, a w jego miejscu pojawił się z czasem grób E61.

\section{FORMA ZEWNĘTRZNA GROBU-MAUZOLEUM}

Przy przyjęciu prezentowanych wyżej założeń podstawowe pozostaje pytanie, jaka zewnętrzna część grobowca była dostępna oglądającym? Wobec braku pełnej stratyfikacji cmentarza (dostępny obserwacji jest jedynie jego najniższy poziom) trudno na nie jednoznacznie odpowiedzieć. Można co najwyżej domniemywać, że podobnie jak to miało miejsce w przypadku pochówków elitarnych Europy 2. połowy X w., zewnętrzną formą pochówka był kopiec, którego wielkość ograniczały wymiary grodzenia D167. Zakładam, że z przyczyn praktycznych (względy komu- 
nikacyjne) maksymalna średnica kopca nie przekraczała 50\% przestrzeni wewnętrznej grodzenia, co oznaczałoby, że wynosić ona mogła co najwyżej $3 \mathrm{~m}$.

Zagadkowe jest pierwotne usytuowanie dużego kamienia $(55 \times 30 \mathrm{~cm})$ o wydłużonej formie, znalezionego powyżej szkieletu w zasypisku komory grobowej (ryc. 9). Nie był to rodzaj kamiennego „zagłówka” umożliwiającego ułożenie głowy zmarłego - co było częstą praktyką potwierdzoną przykładami odkryć z okresu wczesnego średniowiecza (por. Băcueț-Crișan 2015). Możliwości tej przeczy wielkość i miejsce jego znalezienia oraz brak zachodniej orientacji zmarłego. Zdaniem M. Kara umiejscowienie kamienia w narożniku jamy grobowej nasuwa skojarzenia z kamieniem węgielnym przestrzeni sakralnych - umieszczanym na nagrobku lub w grobie, mającym uniemożliwiać powrót zmarłego do świata żywych. Autor ten nie wyklucza też jego komemoratywnych funkcji (Kara 2016a, s. 357; tam dalsza literatura).

Oprócz znaczącej wielkości uwagę zwraca pozycja stratygraficzna kamienia. Zalega on co prawda w narożniku jamy grobowej, ale ponad $20 \mathrm{~cm}$ powyżej poziomu złożenia zwłok zmarłego. Zatem jego kontekstem nie jest dno komory grobowej, lecz jej wypełnisko. Interesujące są niektóre obserwacje dotyczące charakteru wypełnisk jam grobowych. M. Kara (2016a, s. 356, ryc. 4.1.12, s. 357) odnotował, że na cmentarzysku w Bodzi są one najczęściej jednorodne, co sugeruje jednorazową akcję zasypywania grobów. Tymczasem w przypadku grobu D162 jest ono wielowarstwowe i układa się nieckowato. Taki jego charakter wynika, zdaniem tego autora, z faktu, że zasypywanie grobu odbywało się dwuetapowo i z przerwami. Przyczyn tego zjawiska skłonny jest on upatrywać w bliżej nieznanych rytuałach pogrzebowych (tamże, s. 357).

Istnieje również inna możliwość wyjaśnienia tego zjawiska. Wykluczyć nie można, że ów ponadpółmetrowej średnicy głaz o wydłużonej formie - przypominający kamienną stellę - pierwotnie umieszczony został na zewnętrznym nasypie grobowca. Jeżeli poniżej znajdowały się puste przestrzenie (drewniana trumna, obudowa dużej komory grobowej), to obserwacje stratygraficzne dają się tłumaczyć następstwami procesów podepozycyjnych. Innymi słowy, osobliwości stratyfikacji D162 wynikać mogły z powolnej destrukcji i degradacji drewnianych elementów konstrukcyjnych komory grobowej i skrzyni trumiennej, a następnie, wypełnianiem pustych przestrzeni przez składniki glebowe z warstw zalegających powyżej. Tym samym ów głaz - pierwotnie umieszczony na powierzchni grobu - wskutek procesów naturalnych przemieścił się do wnętrza jamy grobowej. Jeżeli tak było, to w kontekście pierwotnym (tu: powierzchnia nagrobka) spełniał on funkcje komemoratywne.

Komemoratywna funkcja kamienia z Bodzi znajduje wsparcie w publikowanych materiałach źródłowych. Na przykład, z terenów Czech znaleziska takie pochodzą z 60 miejscowości i dotyczą ponad 330 (!) znalezisk stelli i płyt kamiennych, datowanych na X-XIII wiek. Znajdowano je zarówno w środowiskach cmentarzy wiejskich, jak i przykościelnych, przy czym wszędzie są określane jako płyty na- 


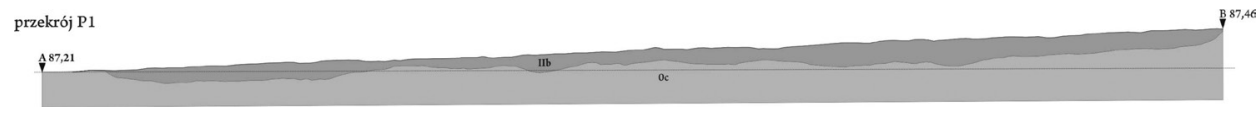

Ryc. 10. Przekrój wzdłużny (P1) przez północny negatyw grodzenia D167. Uwagę zwraca nierównomierny poziom spągu wypełniska. Objaśnienia: IIb - jednorodna, próchniczna warstwa wypełniska, Oc - calec (rys. S. Gronek, opr. komputerowe K. Skrzyńska)

grobne. Większość tych znalezisk nie zawiera żadnych inskrypcji, choć trafiają się również ze znakami krzyża (por. Podhorský, Drnovský 2017). I choć przeważają tam okazy zdecydowanie większe, to występują również zbliżone wielkością do znaleziska z naszego cmentarzyska (tamże, s. 376, ryc. 6).

W kontekście odkryć w Bodzi słabością prezentowanej hipotezy może być brak śladów na obrzeżach jamy grobowej wskazujących, że komora grobowa obudowana była drewnem. Nie jest to jednak argument przesądzający. Dostępne obserwacji archeologicznej były bowiem jedynie jej najniższe części. Ponadto w warunkach geologicznych omawianego cmentarza (gliniasto-piaszczyste podłoże) drewno ulegało najczęściej całkowitemu rozkładowi. Tezę tę potwierdza dowodnie brak drewnianej skrzyni trumiennej w interesującym nas grobie, choć jej świadectwem są udokumentowane in situ żelazne okucia rozmieszczone symetrycznie wokół szkieletu (por. ryc. 3). Drewna brak też w negatywach grodzenia i w negatywach posłupowych grodzenia D167. Można jednak przyjąć, że zalegające tam pierwotnie w rowkach drewno ulegało butwieniu, a następnie całkowitemu rozkładowi. Stąd dostępne obserwacji archeologa pozostają najniższe, negatywowe formy tych konstrukcji (por. ryc. 6).

Kwestią dyskusyjną pozostają ich pierwotne formy. Teoretycznie w grę wchodzą tu zarówno tzw. domy zmarłych, jak i prostsze konstrukcje o charakterze płotu-palisady. Konstrukcja w typie budynku wydaje się w tym przypadku mniej prawdopodobna $^{1}$. Trudno bowiem wytłumaczyć potrzebę układania prostokątnych, drewnianych legarów, tworzących drewniany fundament od ówczesnej powierzchni terenu do głębokości niemal jednego metra (!). Również krawędzie wszystkich czterech negatywów wykazują - jak odnotowano wyżej - lekkie falowanie ich krawędzi (por. ryc. 8). W przypadku legarów drewnianych oczekiwać należałoby nie tylko wyrównanych krawędzi, ale w miarę równego poziomu ich posadowienia, czego w tym przypadku brak (ryc. 10). Stąd uważam, że owe głębokie negatywy są materialnym świadectwem obecności w tym miejscu ściany palisadowej zbudo-

\footnotetext{
${ }^{1}$ W karcie dokumentacyjnej określany jest jako „negatyw po fundamentach konstrukcji z belek drewnianych ociosanych prostokątnych w przekroju, łączonych w konstrukcji zrębowej” (por. karta obiektu nr 167, w Dziale Dokumentacji PMA w Warszawie)
} 

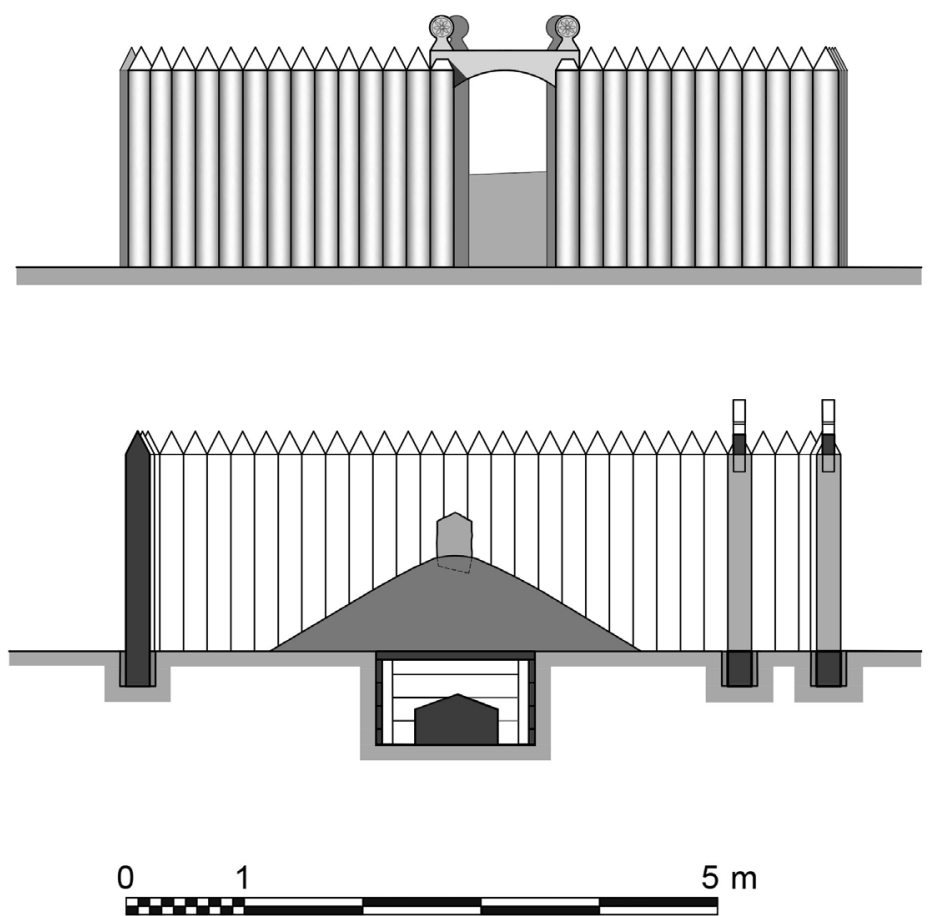

Ryc. 11. Grobowiec D162 w fazie inicjalnej (próba rekonstrukcji): u góry - widok wejścia do grobowca oglądanego od strony wschodniej, niżej - przekrój całości po osi W-E (rys. V. Petryk)

wanej z pali o płaskim zakończeniu - na co wskazuje kształt spągu analizowanych zagłębień. Charakterystyczne przy tym nierówne zarysy ich spągu mogą być świadectwem podobnych, lecz niekoniecznie identycznych, głębokości osadzania pali w gliniastym podłożu. Uwagę zwraca aż 30-centymetrowa szerokość negatywów domniemanej palisady. Wskazuje to na znaczącą średnicę pali, tym samym znaczącą wysokość grodzeń. Wykluczyć nie można, że podobnie jak w przypadku palisady w Jelling (por. niżej), przekraczała ona wysokość $2 \mathrm{~m}$.

Po stronie wschodniej grodzenia domyślać się można obecności wejścia z przedsionkiem. W obrębie tak skonstruowanego grobowca (ryc. 11) umieszczony został centralnie pochówek D162².

${ }^{2}$ Nie odnoszę się w tym miejscu do drugiego rzędu grodzenia, które w myśl prezentowanej koncepcji, łączyć należałoby, z włączeniem w obręb tej kwatery pochówka kobiety (D164) - zidentyfikowanego w pierwotnym ,przedsionku”, zatem z kolejnym epizodem użytkowania grobowca. 


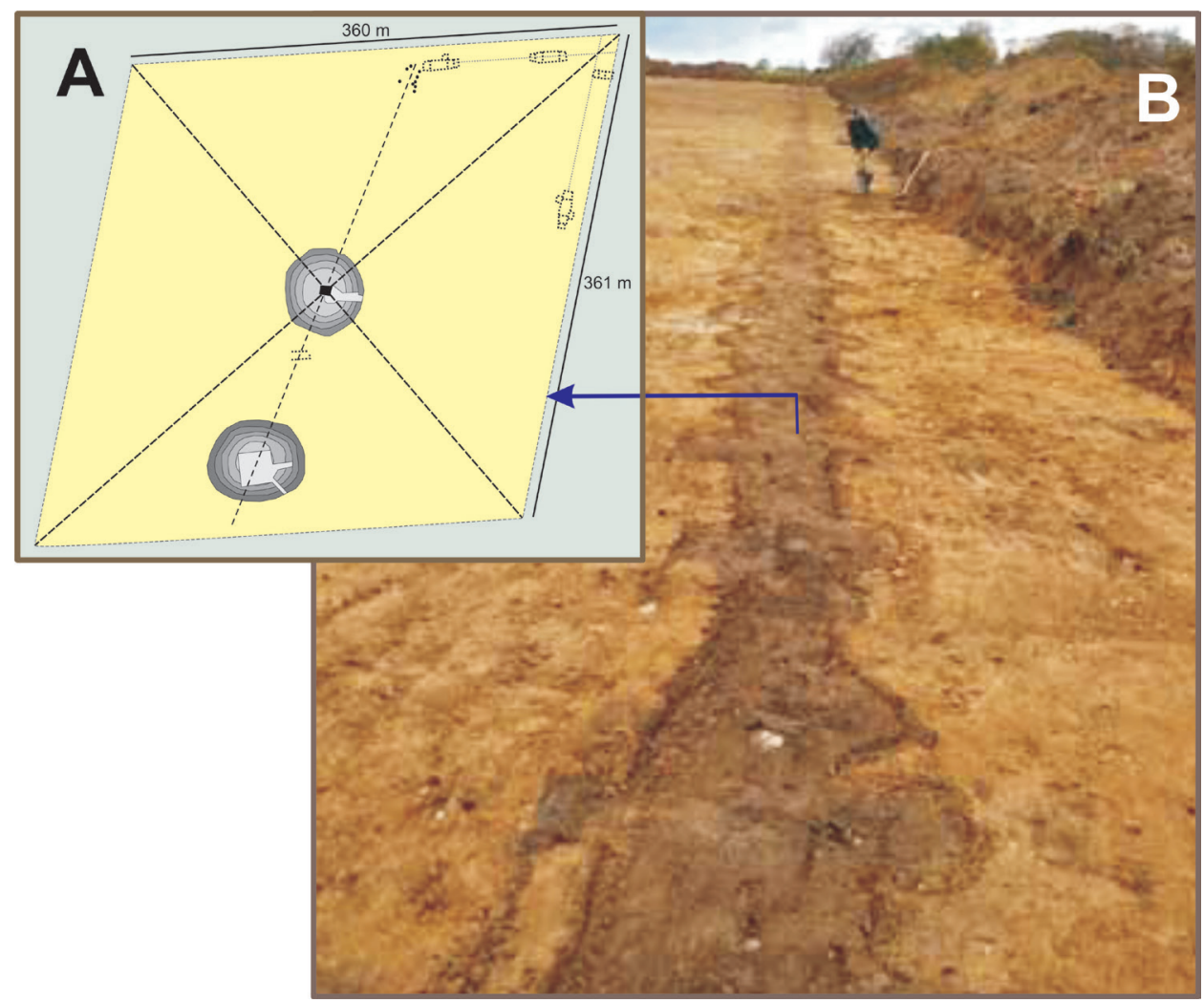

Ryc. 12. Plan i układ przestrzenny kurhanów królewskich w Jelling (A) oraz negatyw wschodni grodzenia palisadowego (B) (wg M.D. Jessen i in., 2012, opr. komputerowe całości K. Skrzyńska)

\section{ŹRÓDŁA IDEOWEJ INSPIRACJI}

Znalezienie analogii do prezentowanej w tym miejscu koncepcji grobu-mauzoleum nie jest łatwe, choć grobowce takie występują w różnych epokach na wielu obszarach geograficznych. W przypadku polskiego wczesnego średniowiecza trudno wszakże pokusić się o bezpośrednie analogie (por. Kara 2016b; Buko 2016, s. 506). Wątpliwym punktem odniesienia wydają się pojedyncze elitarne groby lokowane w obrębie najstarszych cmentarzy wczesnośredniowiecznych, np. grób wojownika z cmentarzyska w Krakowie-Zakrzówku (por. Morawski, Zaitz 1971). Na cmentarzysku w Pniu występuje grób dziecka z grodzeniami otaczającymi kilkakrotnie komorę grobową (por. Janowski 2015, s. 210, ryc. 36), ale zarówno koncepcja przestrzenna tamtejszego cmentarza, jego elementy strukturalne, jak i rodzaj grodzenia oraz charakterystyki tamtejszych zmarłych zdecydowanie się różnią. 
W tej sytuacji warto zatrzymać się nad elementami strukturalnymi grobu D162 w Bodzi. Są tam wyraźnie zaznaczone trzy elementy: 1) położona centralnie duża komora grobowa, 2) wydzielona wokół niej niezabudowana przestrzeń, 3) prostokątne grodzenie palisadowe, zwielokrotnione po stronie wschodniej. Wszystko to przypomina rodzaj sepulkralnej ,posesji” (?) zamkniętej czworobocznym palisadowym płotem.

W poszukiwaniu możliwych kierunków ideowej inspiracji warto odnotować w tym miejscu, że I rząd cmentarza ma silne konotacje kulturowe i genetyczne ze strefą bałtycką (skandynawską?), co potwierdziły badania zawartości izotopów strontu w kościach zmarłych (por. Price, Frei 2016, s. 433, tab. 6.12, ryc. 6.1.6). W tej przestrzeni geograficznej należałoby szukać zatem ewentualnych pierwowzorów dla grobowca $z$ Bodzi. W tym kontekście godne uwagi są nowsze koncepcje dotyczące kurhanów królewskich z duńskiego Jelling, zwłaszcza z II horyzontu czasowego. Odnoszą się doń dwa elitarne kurhany (w tym starszy położony centralnie) umieszczone wewnątrz czworobocznego grodzenia. To ostatnie zachowane jest, podobnie jak w Bodzi, w formie negatywowego odcisku, czytelnego w podłożu (ryc. 12).

Grodzenia kurhanów królewskich z Jelling stanowią konstrukcje palisadowe, na planie lekko trapezowatym o wymiarach 360×361 m (Kähler i in., 2012, s. 490). W tak zaprojektowanej przestrzeni, w miejscu centralnym, usytuowany był pochówek głównego zmarłego. W omawianym przypadku chodzi o grób komorowy wewnątrz kurhanu północnego - identyfikowany z grobem królowej Thyry. Czas jego powstania określany został na lata 958-959. Drugi grób (Gorma) łączony jest z dodanym sukcesywnie kopcem południowym. Oprócz kopca południowego, w części północno-wschodniej grodzenia powstaje wówczas kilka nowych budowli. Opisywane zmiany nastąpiły zapewne jeszcze przed schyłkiem X w. (tamże, s. 493). Podobnie jak to ma miejsce w Bodzi, całość powstała na niezasiedlonym terenie.

Badacze duńscy układ tego zespołu łączą z procesami powstawania struktur władzy i wielkich włości feudalnych w czasach Gorma i Haralda Sinozębego (Jessen $\mathrm{i}$ in. 2011, s. 65 i n.; Holst i in. 2012, s. 502; por. też Krogh 1983; Pedersen 2014). W myśl nowszych koncepcji, plan monumentalnego założenia w Jelling nawiązuje do skandynawskich tradycji rezydencjalnych włości agrarnych, charakterystycznych dla tamtejszych władców i warstw arystokracji. Chodzi zwłaszcza o plan centralnie położonego budynku, usytuowanego w obrębie geometrycznie zaplanowanego, czworobocznego grodzenia palisadowego, wyznaczającego linie demarkacyjne włości feudalnych znanych m.in. z Zelandii i Skanii (Holst i in. 2012, s. 499; Jørgensen 2013). W myśl tej koncepcji, ich symboliczną projekcją byłaby architektura zespołu sepulkralnego w Jelling, usytuowanego w obrębie czworobocznego grodzenia (ryc. 13).

Koncepcję tę wspierają nowsze studia dotyczące topografii zespołów wiejskich terenów wczesnośredniowiecznej Jutlandii (por. Holst 2010). Wskazują one na wielowiekową trwałość czworobocznych parceli, sięgającą od późnego okresu żelaza 

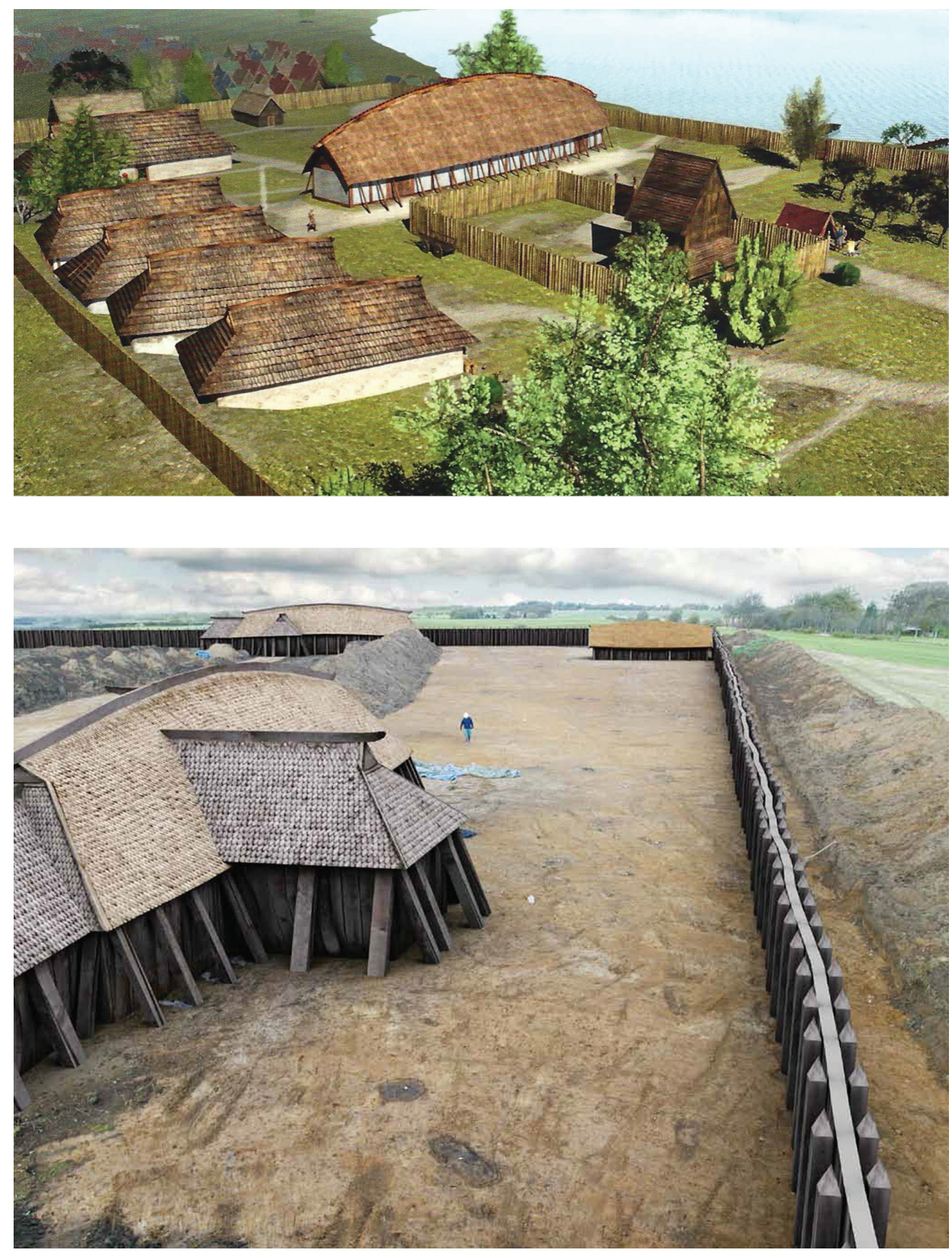

Ryc. 13. Posiadłości władców świata żywych i posiadłości władców świata zmarłych: wyżej - rekonstrukcja czworokątnego grodzenia palisadowego i elementów zabudowy dworu królewskiego w Fuglegård (Tissø) w III fazie funkcjonowania zespołu (ok. roku 900) (wg Jørgensena), niżej - zarys wschodniej linii czworokątnego grodzenia palisadowego i elementów zabudowy wokół kurhanów królewskich w Jelling (wg M.D. Jessen i in.) 

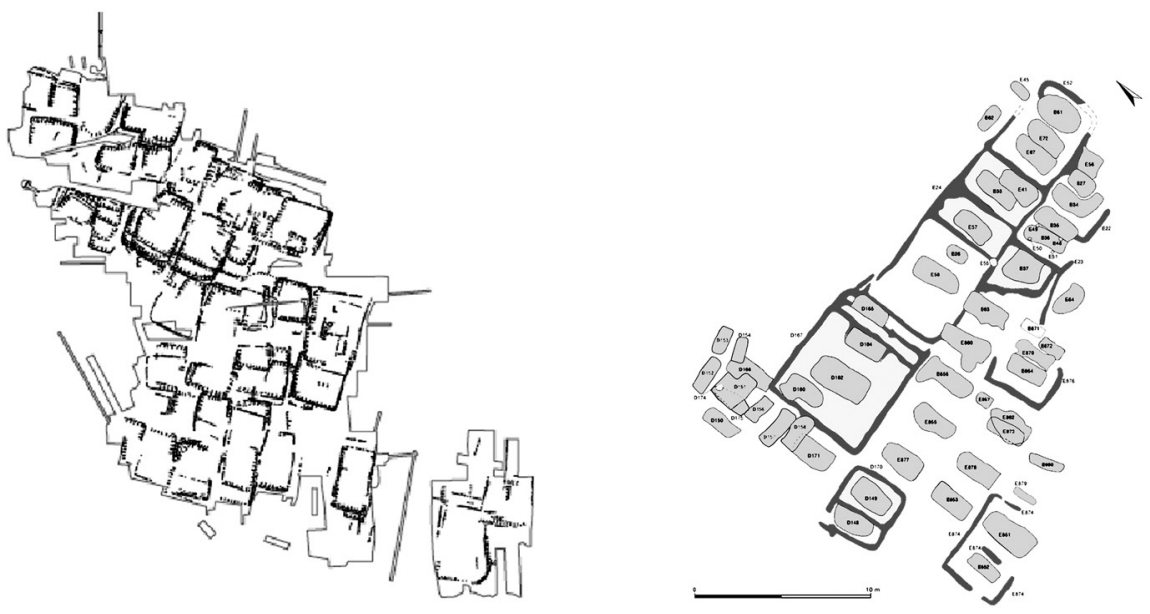

Ryc. 14. Posiadłości elit świata żywych i elit świata zmarłych: po lewej stronie - plan czworobocznych grodzonych palisadą parceli własnościowych na stanowisku Nørre Snede (Jutlandia) - powtarzających ten sam wzorzec zabudowy w długim przedziale czasowym (II-VII w.) (za M.K. Holst); na prawo - układ przestrzenny elitarnych grobów z grodzeniami na cmentarzysku w Bodzi (opr. komputerowe M. Trzeciecki)

po okres wikiński. Ich układ przestrzenny, a dotyczy to działek i ich prostokątnych grodzeń, tworzy przy tym dającą się zidentyfikować w terenie czworoboczną szachownicę. Ten system zabudowy farmowej, mający na Jutlandii korzenie tkwiące w wielowiekowej tradycji (ryc. 14a), rozpoznawalny jest nadal w okresie wikińskim (VIII-X w.) - co wykazały m.in. badania zrealizowane w Vorbasse (tamże, s. 168 , ryc. 7).

Czy i w jakim stopniu podobne symboliczne treści odnieść można do topografii grobu D162 w Bodzi - szerzej całego cmentarza (ryc.14b)? Możliwości takiej nie przeczą dane etnokulturowe. Przeciwnie, rząd I cmentarza, który inicjuje kwatera D162, tkwi głęboko najpewniej w środowisku skandynawskim, ze względu na pochodzenie złożonych tu zmarłych. Od strony wschodniej do grobowca D162 przylega kwatera z prostokątnym grodzeniem mieszcząca szczątki obcego pochodzeniem wojownika z langsaksem (por. wyżej). Również duże, jak w przypadku D162, prostokątne jamy grobowe tego rzędu nawiązują, zdaniem M. Kara (2016a, s. 343; tamże przypis 20) do tradycji duńskich grobów komorowych. Zbliżona jest też chronologia opisywanych zjawisk. Zgodnie z wynikami badań, ten rząd cmentarza w Bodzi zainicjowany został najpewniej jeszcze przed końcem X lub na przełomie X/XI w. (por. Buko, Kara 2016, s. 449 i n.).

Podobnie jak w przypadku Jelling, uwagę zwraca wysoka dynamika przemian zachodzących na cmentarzu w Bodzi w stosunkowo krótkim czasie. W myśl prezentowanej tu koncepcji, w fazie inicjalnej na kulminacji morenowej znajdował się 


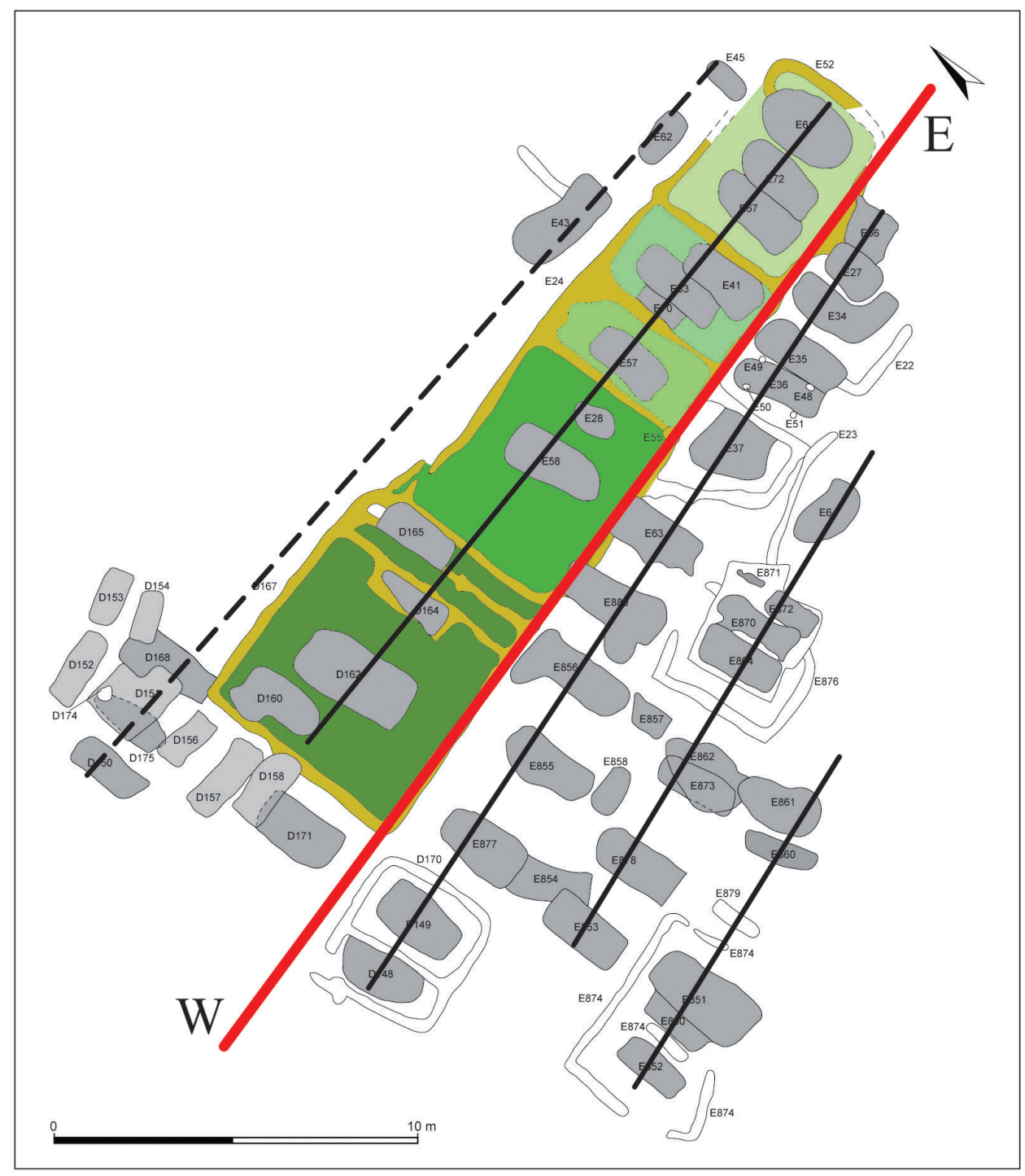

- A $\square-B$

Ryc. 15. Podstawowy podział przestrzeni cmentarza w Bodzi na rząd I - z prostokątnymi grodzeniami, oraz rzędy II-IV z grodzeniami i bez nich. Osią podziału przestrzeni cmentarza jest strona południowa rzędu I (wg A. Buko) 
grobowiec D162 z grodzeniem, a u podstawy wyniesienia, po jego stronie wschodniej - obiekt E52, pozostający z nim w związku funkcjonalnym i chronologicznym (strażnica?). Zapewne jeszcze przed schyłkiem X w. po stronie zachodniej grodzenia pojawił się pochówek męski D160 zdeponowany w obszernej komorze z aneksem. Równocześnie następowało przejście od koncepcji monumentalnego grobowca do elitarnego cmentarza. Polegało ono na zamknięciu (lub modyfikacji) wejścia na teren grobowca widocznego po stronie wschodniej, gdzie dostawiono grodzenie grobu E58 (wojownik z langsaksem), a w miejscu dawnego wejścia znajduje się grób kobiecy D164. Przestał też spełniać swą pierwotną funkcję obiekt E52 usytuowany po stronie wschodniej I rzędu cmentarza, w którego miejscu umieszczony został ostatni w tym rzędzie- grób E81 (por. ryc. 1).

Czy zatem grób D162 jest symboliczną egzemplifikacją w zminiaturyzowanej skali, przestrzeni sepulkralnej, nawiązującej do topografii duńskich włości feudalnych obejmujących parcele zamknięte czworobocznym grodzeniem? Jeżeli tak, to kolejne repliki grodzeń I rzędu cmentarza w Bodzi traktować należałoby jako postępującą miniaturyzację tego wzorca, a kolejne rzędy - jako niewątpliwą hybrydyzację pierwotnej idei (por. ryc. 15).

Jeżeli takie były źródła ideowej inspiracji dla interesującego nas pochówka, tym samym uznać należałoby, że zmarły był przedstawicielem duńskich elit, pochowanym na ziemiach polskich, w tamtejszym rytuale, przysługującym wybitnym przedstawicielom tamtejszej arystokracji. Tymczasem w świetle wyników dotychczasowych badań brak jest podstaw, aby można było uznać go za obcego.

\section{KOGO POCHOWANO W GROBIE D162?}

Jest to pytanie kluczowe dla zrozumienia fenomenu cmentarzyska w Bodzi. Badania izotopów stabilnych strontu wskazują, że zawartości tego składnika we wszystkich trzech przebadanych próbkach - zarówno w szkliwie zębowym, jak i kościach zmarłego -odpowiadają sygnałom miejscowego podłoża (ryc. 16) ${ }^{3}$. Jest to silny argument na rzecz jego miejscowego pochodzenia 4 . Jednak zmarły pochowany został zgodnie z rytuałami obcymi dla interesującego nas regionu i szerzej - ziem polskich. Co więcej, w tym samym rzędzie występują nie tylko naśladowcy niemiejscowej tradycji grzebalnej, ale osobnicy, co do których wyniki analizy izotopów stabilnych wskazują na ich obce (skandynawskie?) pochodzenie (por.

3 Badania z inicjatywy dr. Dariusza Błaszczyka przeprowadzono w Poznańskim Laboratorium Izotopowym UAM w Poznaniu pod kierunkiem prof. Zdzisława Bełki.

4 Określenie „miejscowego pochodzenia” ma w tym przypadku szersze znaczenie i odnosi się do zawartości izotopów strontu w kościach zwierząt pochodzących z podobnych kontekstów stratygraficzno-chronologicznych Bodzi i okolic. Nie mamy dotąd dostatecznej liczby danych dotyczących poziomu izotopów strontu dla całego obszaru ziem polskich, tym samym pozwalających uprecyzyjnić to stwierdzenie. 


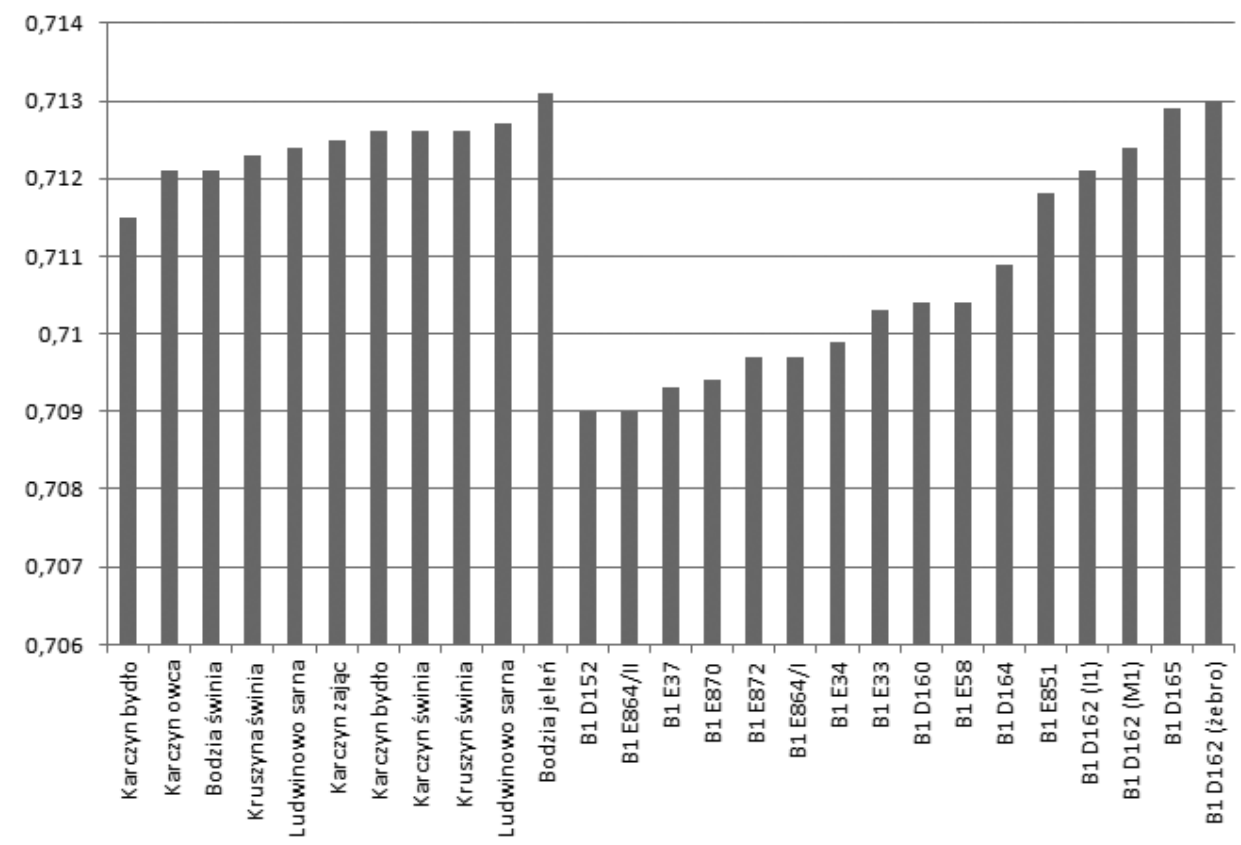

Ryc. 16. Wyniki analiz izotopów strontu zrealizowanych dla lokalnej fauny i części pochówków z cmentarzyska w Bodzi: po lewej stronie (wysokie słupki na diagramie) - zawartości izotopów strontu w kościach zwierząt stanowiących lokalne tło porównań; po prawej stronie - zawartości izotopów strontu w kościach zmarłych. Pochówek D162 (3 próbki) o wysokich zawartościach strontu (sygnał miejscowy) znajduje się po prawej stronie diagramu (opr. D. Błaszczyk)

Price, Frei 2016). W grupie tej mieszczą się m.in. dwa groby zidentyfikowane wewnątrz tego samego grodzenia co D162, w tym kobieta z grobu D164, którą - co warto odnotować - jako jedyną na analizowanym cmentarzu złożono w identycznie ukształtowanej trumnie jak osobnika z grobu D162.

W świetle wyników przeprowadzonych badań przyjąć należałoby, że osobnik ten, urodzony co prawda na ziemiach polskich, znaczną część swego życia spędził poza krajem (w Skandynawii?). Tam mógł nabyć nie tylko różnorakich umiejętności, ale też dojść do wysokiej pozycji w tamtejszej drabinie hierarchii społecznej. W ślad za tym należałoby przyjąć, że na pewnym etapie życia swe dalsze losy związał z krajem urodzenia 5 . Pochowano go bowiem (podobnie jak i innych z interesującego nas cmentarza) niedaleko Włocławka - jednego z głównych ośrodków

5 Na słowiańskich wojowników służących w oddziałach duńskiego króla Haralda Sinozębego, którzy zdobywali tam doświadczenie i mogli powracać z czasem do kraju pochodzenia, zwracał ostatnio uwagę M. Bogucki (2016b). 
państwa Mieszka i Chrobrego. Ale forma i niecodzienne elementy składowe grobowca, w tym północna orientacja zmarłego są odmienne od stosowanych w tym czasie rytuałów na ziemiach polskich. Tym samym pozostają wyrazistym znakiem obcej tożsamości etnokulturowej zmarłego.

Jeżeli przypuszczenia te są słuszne, to mielibyśmy pierwszy poświadczony archeologicznie przypadek elit czasów Mieszka i Chrobrego wywodzących się z ziem polskich, zdobywających życiowe doświadczenie i wysoki status społeczny za granicą, by w kraju urodzenia budować zręby polskiej państwowości i tutaj dokonać swego żywota.

Nie odpowiemy w tym miejscu na pytanie, czy obcy naśladowcy rytuałów pogrzebowych osobnika z grobu D162, pochowani w tym samym I rzędzie cmentarza, przybyli z nim razem, czy też ich pojawienie się w piastowskim środowisku miało inne przyczyny. Nie podlega natomiast dyskusji silna więź etnokulturowa tej grupy zmarłych zarówno z pochówkiem D162, jak i środowiskiem bałtyckim (skandynawskim). Poświadczeniem tej tezy jest przestrzeganie wzorca chowania zmarłych w kolejnych grodzeniach tego samego rzędu, w tym pozostawiająca wiele do myślenia ,północna” orientacja pochówków ${ }^{6}$, obce elementy kulturowe (np. wojownik z langsaksem) i - co najważniejsze - wyniki analiz izotopów strontu, wskazujących na ich obce (,bałtyckie”) pochodzenie.

Niektóre przesłanki wskazują, że osobnik D162 był nie tylko przedstawicielem elit czasów Mieszka i Chrobrego, ale mógł być również postacią charyzmatyczną. Wynika to nie tylko z naśladownictwa wzorca grobu D162 przez innych zmarłych chowanych na cmentarzu w Bodzi. Uwagę zwraca fakt, że przeważająca liczba pochówków (aż 11 osobników) znajdujących się poza rzędami cmentarza, zostało złożonych przy interesującym nas grobie. Czyżby, w przekonaniu ówczesnych, promieniowała stąd jakaś nieznana, pozytywna energia? Odnotujmy, że chodzi tu zarówno o groby należące do fazy starszej, jak i groby inicjujące młodszą (XI-połowa XII w.) fazę cmentarza (por. ryc. 15). Co więcej, żaden z grobów fazy młodszej cmentarza, przylegając do grodzenia, nie niszczy tej kwatery. Oznaczać to może, że jeszcze w okresie II monarchii piastowskiej pamięć o cmentarzu była nadal żywa, a jego elementy zewnętrzne pozostawały widoczne na powierzchni.

Osobnik z grobu D162 pochowany został najpewniej w ostatniej dekadzie X w., zatem okres jego aktywności odnieść należy do czasów panowania Mieszka I. $\mathrm{Z}$ jaką postacią historyczną tych czasów można go wiązać? Pytanie to, wobec milczenia źródeł pisanych na ten temat, pozostaje nierozstrzygniętą zagadką.

${ }^{6} \mathrm{~W}$ opiniach wielu autorów jest to starsza (sprzed czasów Karola Wielkiego) tradycja grzebalna znana na szerokich terytoriach zwłaszcza północno-zachodniej Europy (szerzej na ten temat: A. Gräslund 1989, s. 47 i n.; w cytowanej pracy literatura). 


\section{DYSKUSJA}

Przedstawiona wyżej propozycja czerpie z nowszych doświadczeń badaczy duńskich. Tamtejsze punkty odniesienia wydają się bowiem na obecnym etapie badań najbardziej uzasadnione etnokulturowo i chronologicznie. I choć na wsparcie proponowanej hipotezy przedstawiono wiele istotnych przesłanek, to nadal kilka kwestii szczegółowych pozostaje poza zasięgiem obserwacji. W przypadku prezentowanej na stronach artykułu rekonstrukcji grobowca D162 nie do końca wiadomo, jak wyglądały grodzenia na poziomie użytkowym w fazie funkcjonowania cmentarza, w tym ich rzeczywista wysokość. $Z$ kolei sugerowane wejście po stronie wschodniej zawiera odciski negatywowe trudne do jednoznacznej interpretacji. W szczególności niejasno rysuje się charakter domniemanego wejścia- po wbudowaniu doń grobu D164. Nie wiemy też, kim byli ludzie pochowani w obrębie grodzenia D167 i jakie więzy łączyły ich z głównym zmarłym. Wykluczyć nie można, że grób D165 określony wynikami badań izotopów strontu jako należący do osobnika miejscowego, w rzeczywistości kryje szczątki tutaj urodzonych dzieci migrantów - czego przedmiotowe badania nie są w stanie wychwycić. Pożądane w tym względzie byłyby zatem dalsze badania izotopowe i genetyczne kości kolejnych zmarłych. Kwestią dyskusyjną pozostaje też sugerowana w monografii Bodzi (Buko, Kara 2016, s. 448) kwestia naruszenia przez grodzenia D167 komory grobowej D168 - kobiety w wieku maturus pochowanej poza rzędami grodzeń. Zdaniem piszącego te słowa, zarówno w oryginalnych materiałach dokumentacyjnych ${ }^{7}$, w tym na przerysach planu cmentarza i dostępnych materiałach fotograficznych, negatyw grodzenia D167 nie tyle narusza jamę grobową pochówka D168, ile doń przylega (por. ryc. 7, 15).

Problemów interpretacyjnych przysparza też lokalizacja stref wejścia w obręb kwater grobowych, jakie musiały powstać po dobudowaniu do grobu D162 kwatery grobu E58 i kolejnych tego rzędu. Na obecnym etapie badań uzasadnione wydaje się przyjęcie założenia, że po przekształceniu grobu-mauzoleum D162 w elitarny cmentarz, dostęp do kwater I rzędu znajdował się po stronie północnej cmentarza. Tu bowiem była jedyna wolna (niekolizyjna) przestrzeń, jako że od południa do grodzeń przylegają grobowce II rzędu. Gdzie owe wejścia się znajdowały i jaką miały formę - trudno rozstrzygać wobec faktu, że dostępny obserwacji archeologicznej jest najniższy (ciągły) negatywowy poziom grodzeń. Nie wiemy więc, czy kolejne grodzenia powielały formą D167, jak były wysokie i czy miały charakter ciągły.

Bez ostatecznych rozstrzygnięć pozostaje też wiele kwestii sygnalizowanych na stronach opublikowanych monografii. Dla piszącego te słowa pozostaje tajemnicą, dlaczego w Skandynawii wczesnośredniowiecznej, podobnie jak na ziemiach pol-

\footnotetext{
7 Odpowiednie kwerendy źródłowe przeprowadził autor artykułu w Dziale Archeologii Średniowiecza Państwowego Muzeum Archeologicznego w Warszawie we wrześniu 2017 roku.
} 
skich, tak oryginalne plany i elementy strukturalne zespołów sepulkralnych jak w duńskim Jelling czy w usytuowanej na ziemiach polskich Bodzi nie znalazły $\mathrm{w}$ innych miejscach $\mathrm{i}$ w podobnym czasie naśladownictwa i kontynuacji. Wszystko to sprawia, że grób D162, podobnie jak i cały cmentarz, pozostaną przedmiotem badań i krytycznych weryfikacji również w najbliższej przyszłości.

\section{BIBLIOGRAFIA}

Wykaz skrótów

Bodzia... - Buko A. (red.), Bodzia. Elitarny cmentarz z poczatków państwa polskiego, Warszawa 2016.

Wykaz cytowanej literatury

Băcueț-Crișan D. 2015, Pagans or christians in the early mediaeval cemetery from zalău "valea răchişorii / pálvár"? in: S.A. Cociș, V.A. Lăzărescu, M. Gui, D.A. Deac eds, Ad finem imperii romani, studies in honour of Coriolan H. Opreanu, Cluj-Napoca, s. 71-83.

Bogdanowicz W., Grzybowski T., Buś. M.M. 2016, Analiza genetyczna wybranych grobów z cmentarza z Bodzi, w: Bodzia..., s. 437-445.

Bogucki M. 2016a, Szlaki handlowe środkowej i dolnej Wisty w X-XI w. w świetle danych archeologicznych, w: Bodzia..., s. 17-32.

- 2016b, Intercultural relations of the inhabitants of Polish territory in the $9^{\text {th }}$ and $10^{\text {th }}$ centuries, w: M. Trzeciecki (red.), The Past Societies. Polish Lands from the first evidence of human presence to the Early Middle Ages, , vol. V, 500-1000 AD, Warszawa, s. 223-276.

Buko A. 2016, Cmentarzysko w Bodzi w świetle wyników badań interdyscyplinarnych, w: Bodzia..., s. 489-507.

Buko A., Kara M. 2016, Chronologia cmentarza, w: Bodzia...., s. 446-452.

Buko (red.) 2015, Bodzia. A Late Viking- Age Cemetery in Central Poland, Leiden-Boston.

- 2016, Bodzia. Elitarny cmentarz z początków państwa polskiego, Warszawa.

Buko A., Kara M., Price D., Duczko W., Frei K, Sobkowiak-Tabaka I. 2013, A unique medieval cemetery from the 10th/11th century with chamber-like graves, „Archäologisches Korrespondenzblatt“, Jahrgang 43, Heft 3, s. 423-442.

Goslar T. 2016, Wyniki kalibrowanych datowań radiowęglowych prób z cmentarzyska w Bodzi wykonanych w Poznańskim Laboratorium Radiowęglowym metoda 14C AMS, w: Bodzia..., s. 453-454.

Gräslund A.S. 1980, Birka, IV: The Burial Customs. A study of the graves on Björkö, Stockholm.

Holst M.K. 2010, Inconstancy and stability-Large and small farmsteads in the village of Nørre Snede (Central Jutland) in the first millennium $A D$, "Siedlungs- und Küstenforschung im südlichen Nordseegebiet", 33, Rahden/Westf., s. 155-179.

Holst M.K, Jessen D.M., Andersen S.W., Pedersen A. 2012, The Late Viking-Age Royal Constructions at Jelling, central Jutland, Denmark. Recent investigations and a suggestion for an interpretative revision, "Praehistorische Zeitschrift", 82 (2), s. 474-504.

Jagodziński M.F. 2010, Truso. Między Weonodlandem a Witlandem, Elbląg.

Jessen M.D, Andersen S.W, Holst M.K, Jensen P. Pedersen A. 2011, Kongens gård i Jelling? - et nyt anloeg fra Harald Blåtands tid, P.K. Madsen, I. Wass eds., Nationalmuseets Arbejdsmark, s. 60-73.

Kara M. 2016a, Organizacja przestrzeni grzebalnej, rytuat i obrzadek pogrzebowy, w: Bodzia..., s. 329-380.

- 2016b, Cmentarzysko w Bodzi w kontekście praktyk funeralnych ludności ziem polskich 2. połowy X-XI w., w: Bodzia..., s. 481-486. 
Kowalska A.B. 2016, Skórzane elementy stroju w pochówkach na wczesnośredniowiecznym cmentarzysku w Bodzi, w: Bodzia..., s. 253-264.

Krogh K.J. 1983, The Royal Viking-Age Monyments at Jelling in the light of Recent Archaeological Excavations. A Preliminary Report, "Acta Archaeologica", 53, s. 183-216.

Krąpiec M. 2016, Wyniki kalibrowanych datowań radiowęglowych prób z cmentarzyska w Bodzi wykonanych metoda konwencjonalna w Laboratorium Datowań Bezwzględnych w Cianowicach k. Krakowa, w: Bodzia..., s. 455-458.

Morawski W., Zaitz E. 1977, Wczesnośredniowieczne cmentarzysko szkieletowe w Krakowie na Zakrzów$k u$, ,Materiały Archeologiczne” 17, s. 53-169.

Pedersen A. 2014, Jelling in 10. Jahrhundert - Alte Thesen, neue Ergebnisse, in: Die Wikinger und Fränkische Reich. Identitäten zwischen Konfrontation und Annäherung, Hofmann P.H., Kamp H., Wemhoff M., eds., Padeborn, s. 275-295.

Podhorský J. Drnovský P. 2017, Raně středověké náhrobniky z Čech, „Archeologie ve středních Čechách", 21, s. 373-407.

Price T.D., Frei K.M. 2016, Badania izotopowe pochówków z Bodzi, w: Bodzia..., s. 425- 436.

Sawicki T. 2016, Próba rekonstrukcji skrzyń trumiennych, w: Bodzia..., s. 381-406.

Sobkowiak-Tabaka I. 2016, Katalog grobów i ich wyposażenia (wersja skrócona), w: Bodzia..., s. 66-81.

Suchodolski S. 2016, Obol zmarlych, w: Bodzia, s. 285-304. 